\title{
Dynamics of Poverty in Developing Countries: Review of Poverty Reduction Approaches
}

\author{
Patrick Brandful Cobbinah ${ }^{1}$, Rosemary Black ${ }^{1} \&$ Rik Thwaites $^{1}$ \\ ${ }^{1}$ School of Environmental Sciences, Institute for Land, Water and Society, Charles Sturt University, Australia \\ Correspondence: Patrick Brandful Cobbinah, School of Environmental Sciences, Institute for Land, Water and \\ Society, Charles Sturt University, Australia. E-mail: pcobbinah@csu.edu.au
}

Received: March 23, 2013 Accepted: August 4, 2013 Online Published: August 9, 2013

doi:10.5539/jsd.v6n9p25 URL: http://dx.doi.org/10.5539/jsd.v6n9p25

\begin{abstract}
The term poverty has been described in different ways throughout the world due to its multidimensional nature. Whereas some countries and geographical regions view poverty as deprivation, others are concerned with social exclusion and inequality in resource distribution. Despite the differences in poverty interpretations, many countries in the developing world have adopted universal poverty reduction approaches over the years. This paper analyzes the conceptual underpinnings of poverty focusing on its evolution, the multidimensional definitions, and poverty reduction efforts implemented over the past 50 years. Using secondary data analysis, the paper reveals the universal approaches to poverty reduction have yielded few successes, and recommends that poverty should be viewed as a global phenomenon but tackled at the local level using local indicators. To achieve sustainable development, developing countries should focus on meeting the basic needs of their inhabitants and be committed to ensuring stable political and economic environment.
\end{abstract}

Keywords: developing countries, poverty, poverty reduction, sustainable development

\section{Introduction}

Poverty is one of the most widespread and persistent social problems in the world especially in the developing countries (Deguara, 2008; Knowles, 2000; Lehning, Vu, \& Pintak, 2006; Todaro \& Smith, 2006). However, it continues unabated despite many efforts by national and international community (Atinmo, Mirmiran, Oyewole, Belahsen, \& Serra-Majem, 2009). Global statistics on poverty are alarming, as close to half of the world's seven billion people live on less than US\$2 a day, and are denied basic human development opportunities such as education, health, dignity, freedom, socio-political participation and access to resources (Singleton, 2003; Vollmer, 2010). According to Bastiaensen, De Herdt and D'Exelle (2005) poverty is not an individual characteristic, but rather characterizes the situation in which individuals or groups of people find themselves at a point in time, making poverty an intractable problem for social scientists and policymakers (Rupasingha \& Goetz, 2003).

The most widely held view is that poverty is detrimental to sustainable development, and that it encourages "negative and unsustainable natural resource exploitation practices" (Ashiomanedu, 2008, p.156). Pearce and Barbier (2000) observe that the relationship between the environment and the economy is central to sustainable development, thus worsening poverty condition is detrimental to development and environmental conservation objectives. Owing to the challenge poverty poses to sustainable development, poverty eradication has become the "greatest global challenge facing the world today and an indispensable requirement for sustainable development, particularly for developing countries" (United Nations [UN], 2002, p.9). As a result the "nature and causes of poverty and interventions to improve the living conditions of the poor continue to be a priority area of research" (Rao, 2003, p.2).

Given that over 2.5 billion people in the world earn an income of US\$ 2 or less a day and are confronted with the reality and severity of poverty (Watkins, 2005), both the developed and the developing countries are seeking sustainable solutions to the phenomenon (Morazes \& Pintak, 2006). Current global commitment to reduce poverty is shown through the adoption of the Millennium Development Goals (MDGs) (UN, 2010). However as Domfeh and Bawole (2009) claim, the form and nature of poverty vary from one region to the other. This paper therefore examines the historical trend of poverty discussions and the multidimensional definitions of poverty 
with reference to the developing countries. The paper further reviews the poverty reduction programs implemented over the past 50 years, their successes and challenges.

\section{Method}

This review is based on the analysis of old and recent literature. It examines the evolution and interpretations of poverty. Moreover, the review accentuates divergent views with regard to the concept of poverty and further highlights the differences in interpretations in the developing countries based on recent discussions on the concept.

Two approaches were employed for this study: (1) Review of peer-reviewed and edited literature from published sources such as books and journal articles. Various terms relating to the concept were used in undertaking the web search in major electronic databases such as Academic search complete, SAGE Journals online, JSTOR and CABI, as well as catalogues from the Australian Library. (2) Analysis of published documents from international organizations which are involved in poverty, development and sustainability issues including the World Bank, UN, United Nations Development Program (UNDP), Organization for Economic Cooperation and Development (OECD) and the United Nations Education, Scientific and Cultural Organization (UNESCO). Literature obtained from the two sources was integrated and structured to focus on cases that provided relevant evidence to the subject being reviewed.

\section{Historical Analysis of the Concept of Poverty}

Poverty is endowed with a rich vocabulary in all cultures, regions and throughout history (Simon, 1999). This section examines the focus and indicators of poverty as well as the challenges of addressing poverty over the past 50 years. According to the Random House Webster's unabridged dictionary, the origin of the concept 'poverty' can be traced back to the $12^{\text {th }}$ century, when the word was used primarily to refer to 'small means or moderate circumstances' (Random House Incorporated, 2009). The concept, however, lacked clarification as to what "constitutes small means or moderate circumstances, and basically hints towards both, poverty as means (inputs, such as commodities and income) and ends (opportunities and status in society)" (Vollmer, 2010, p.69). Due to the uncertainties regarding the specification of the term, Hobsbawm (1972), in the article 'The social function of the past', outlined several factors including culture, space, time, philosophical worldviews, customs and conventions of society that have led to different interpretations and focus of the concept 'poverty'.

According to Simon (1999), poverty was perceived on the basis of 'subsistence needs' and used indicators such as availability of food, clothing and shelter in the $19^{\text {th }}$ century. This was linked to Rowntree's publication in 1901, which was the first to develop a poverty standard for individual families, based on estimates of nutritional and other requirements (Simon, 1999). This interpretation and focus of poverty evolved from the 1900s to 1960s where more emphasis was placed on economic indicators, and poverty was determined based on per capita income (GDP) (Vollmer, 2010). The economic indicators used shifted the poverty focus from 'subsistence needs' to 'economic growth' (increase in production of goods and services) to the neglect of other socio-cultural factors such as education, housing, health and clothing (Simon, 1999). By the late 1960s, people began to question the economic definition of poverty because the model which explained poverty primarily according to economic criteria had social and political problems. These problems included the collapse of social and political structures resulting in an increase in crime, deprivation and dependency as well as increasing inequalities among individuals, groups and regions (Seers, 1969; Thompson, 1981). The definition of poverty was further developed beyond the scope of 'economic indicators' to focus on satisfaction of 'basic needs' (Seers, 1969). Seers (1969) identified 'basic needs' to include income, employment and physical necessities for a basic standard of living (e.g. shelter, public goods and food).

Despite the focus on the 'basic needs', poverty was largely defined in the late 1960s in economic terms. In the 1970s, these problems associated with economic definition of poverty led to the formulation of a 'new' interpretation and focus which was concerned with human welfare. This new focus explained poverty within the broader concept of development. This concern was first expressed in a statement known as the 'Cocoyoc Declaration' which states:

"Our first concern is to redefine the whole purpose of development. This should not be to develop things but to develop man. Man has basic needs - food, shelter, clothing, health and education. Any process of growth that does not lead to their fulfillment or even worse, -disrupts them is a travesty of the idea of development" (Ghai 1977, p.6).

This new focus of poverty emphasized the need for considering equitable distribution of national wealth. This was preceded by Robert MacNamara's celebrated speech on equitable distribution of wealth presented to the 
World Bank Board of Governors in Nairobi in 1973 (Simon, 1999). This new way of defining poverty was characterized by indicators such as the general quality of human life (United Nations Research Institute for Social Development) and the natural environment (United Nations Environment Program). Other social indicators were highlighted by the UNDP and they included living a long and healthy life, being educated, and enjoying a decent standard of living (UNDP, 1990).

During the early 1980s, there was a shift of focus from basic needs to economic means of defining poverty with increasing concentration on income deprivation as indicator. According to Vollmer (2010), this situation emanated as a result of increased dominance of neo-liberals in the World Bank and the International Monetary Fund (IMF). Despite the dominance of public and policy debate on the concept of economic deprivation of poverty (Vollmer, 2010), there were several studies on non-monetary well-being, such as empowerment, social inclusion, education, health and nutrition, which gained global attention during this period (Chambers, 1983; World Bank, 1980). The mid 1980s witnessed the broadening of the concept of poverty to a wider construct, 'livelihood' and was adopted by the Brundtland Commission on Sustainability and Environment, which popularised the term 'sustainable livelihood' (Simon, 1999; World Commission on Environment and Development [WCED], 1987). In the late 1980s, the poverty debate gradually shifted its focus from economic means alone to include culture and gender with policies to empower women (Simon, 1999). Since the late 1980s, several studies have been carried out on culture and gender in relation to poverty (e.g. Longres, 2000; Schriver, 2004). Longres (2000), for example, discusses poverty by examining culture and ethnicity, as well as minority experiences, while Schriver (2004) explains poverty by probing into issues of gender, sexual orientation, ethnicity and individual families living in poverty.

During the 1990s, the economic focus of 'poverty' was highly contested by many researchers and international organizations such as UNDP (1990) and Sen (1992, 1996). Simon (1999, p.2) indicates that "the idea of well-being came to act as a metaphor for absence of poverty, with concomitant emphasis on how poor people themselves view their situation". Consequently, the launching of the UNDP 'Human Development Report' in 1990 focused on social well-being by enlarging peoples' choices taking into consideration individuals physical conditions. The influence of UNDP and some researchers (Nussbaum \& Sen, 1993; Sen, 1992; UNDP, 1990) during the 1990s resulted in a different focus of poverty. Poverty was then focused on economic (income poverty) and non-economic (human poverty) factors. The economic (income) poverty, according to the World Bank, refers to individuals earning incomes less than US $\$ 1.25$ a day for the poorest countries and US $\$ 2$ a day for poor developing countries (Noble, Ratcliffe \& Wright, 2004; Ravalion, 2003; UNDP, 2005). With regard to the non-economic (human poverty), Sen (1992) puts human beings at the center of policy, plan and program through the allocation of entitlements including command of resources. Vollmer (2010, p.75) adds that "these entitlements were created through endowments (assets owned) and exchanges (production and trade by the individual) and that many of these entitlements take place in the non-monetary/non-marketed economy (in the subsistence)". The achievement of conditions of individual well-being requires policies that focus on the enhancement of people's capabilities (Vollmer, 2010). As a consequence, the World Bank report 'Voices of the poor' validates the importance of entitlements in improving the well-being of the poor through asset endowments (natural, social, financial, human and material assets). Equity in the distribution of assets is also a critical indicator in improving the well-being of the poor (World Bank, 1999).

From the mid 1990s and early 2000s, there were several international congresses (UN, 1995) which viewed poverty as a 'multidimensional phenomenon' and notable among them was the Copenhagen World Summit on Social Development 1995 (Sumner, 2007). Recognizing the multidimensional nature of poverty in the $21^{\text {st }}$ century, the World Bank in the 'World Development Report 2000' explained poverty "as a pronounced deprivation in well-being" characterized by hunger, lack of shelter and clothing, sicknesses and diseases, and illiteracy. The focus was on poor people as they are "particularly vulnerable to adverse events outside their control and are often treated badly by state institutions and society as well as being excluded from voice and power in those institutions" (p.15).

Thus, the multidimensional nature of poverty "arises when people lack key capabilities, and so have inadequate incomes or education, or poor health, or insecurity, or low self-confidence, or a sense of powerlessness, or the absence of rights such as freedom of speech" (Haughton \& Khandker, 2009, p.2). Inherent in the multidimensional nature of poverty are multiple deprivations (low income, poor housing, poor access to education and health), and the process by which multiple deprivation occurs (Simon, 1999). Table 1 shows the focus and indicators of the concept of poverty from the 1960s to 2000s.

The complexities surrounding the focus of poverty over the years paved the way for better indicators focusing on the multidimensionality of poverty in what has become known as the MDGs (UN, 2000; Vollmer, 2010), and 
represent the most widely accepted and high-profile statement of international commitment to reduce the number of people living in poverty particularly in the developing countries (Jamieson \& Nadkarni, 2009). Although the MDGs further emphasize the economic focus of poverty and explain poverty as individuals living on less than US\$1.25 or US\$2 per day (Jamieson \& Nadkarni, 2009), other socio-cultural indicators of poverty such as literacy rate, participation, environmental conservation and healthy life are covered by the MDGs (UN, 2000; Sumner, 2007).

Table 1. Focus, indicators and challenges of the poverty concept, 1960s - 2000s

\begin{tabular}{|c|c|c|c|}
\hline Period & Focus & Indicators & Challenges \\
\hline $1960 s$ & Economic growth & $\begin{array}{l}\text { Growth in per capita income } \\
\text { (GDP) }\end{array}$ & $\begin{array}{l}\text { Social and political problems such as } \\
\text { deprivation, inequality and dependency }\end{array}$ \\
\hline $1970 \mathrm{~s}$ & $\begin{array}{l}\text { Basic needs, } \\
\text { welfare and } \\
\text { economic growth }\end{array}$ & $\begin{array}{l}\text { Provision of services such as } \\
\text { education, health and shelter, } \\
\text { Redistribution with growth }\end{array}$ & $\begin{array}{l}\text { Increased dominance of neo liberals in } \\
\text { the World Bank and IMF leading to } \\
\text { income definition of poverty }\end{array}$ \\
\hline $1980 \mathrm{~s}$ & $\begin{array}{l}\text { Income, } \\
\text { sustainable } \\
\text { livelihood, culture } \\
\text { and gender }\end{array}$ & $\begin{array}{l}\text { Establishment of Breton Woods } \\
\text { Institutions and emergence social } \\
\text { development activists }\end{array}$ & $\begin{array}{l}\text { Overemphasis of economic } \\
\text { conceptualisation of poverty }\end{array}$ \\
\hline $1990 \mathrm{~s}$ & $\begin{array}{l}\text { Human } \\
\text { development }\end{array}$ & $\begin{array}{l}\text { Human development indices (both } \\
\text { economic and non-economic)such } \\
\text { as income and command over } \\
\text { resources }\end{array}$ & $\begin{array}{l}\text { Less emphasis on the natural } \\
\text { environment }\end{array}$ \\
\hline $2000 \mathrm{~s}$ & $\begin{array}{l}\text { Human } \\
\text { development and } \\
\text { environmental } \\
\text { sustainability }\end{array}$ & Millennium Development Goals & \\
\hline
\end{tabular}

\section{Defining the Multidimensional Concept of Poverty}

Although, the concept of poverty has evolved over the past half a century, there is little resemblance of definitional consensus amongst stakeholders. Since its recognition and dominance in international and national discussions, different writers, researchers and international organizations have provided different definitions to the concept of poverty (Pillari \& Newsome, 1998; Sen, 2000; Townsend, 1979). As a result, even academic interest has become fashionable with scholars actively engaged in the challenging task of defining the concept of 'poverty' (Sen, 2000; Vollmer, 2010). The burgeoning interests and the proliferation of poverty interpretations which use several terms (e.g. income, human development) to define and measure the concept coupled with a lack of universally agreed definition have resulted in a great deal of confusion among stakeholders, regarding the true meaning of the concept. This section reviews the definitions of poverty that depict and address its multidimensional character in relation to the situation in the developing countries.

As Pillari and Newsome (1998) claim, poverty can be defined as a structural problem causing homelessness, unemployment, and oppression. Sen (2000, p.3), being challenged with the multidimensional nature of the concept, indicates that "poverty must be seen in terms of poor living, rather than just as lowness of incomes and nothing else". Poverty is basically about inadequate or lack of resources which makes participation in political processes and socio-economic activities impossible (Whelan, 2007). This definition of the concept is encapsulated in a broader definition given by Townsend (1979):

“... individuals, families and groups in the population can be said to be in poverty when they lack the resources to obtain the type of diet, participate in activities and have the living conditions and amenities which are customary, or are at least widely encouraged or approved, in the society to which they belong. Their resources are seriously below those commanded by the average individual or family that they are, in effect, excluded from ordinary living patterns and activities" (p. 31).

Townsend's (1979) definition of poverty broadens the scope of poverty as deprivation indicating its relativity and the dualistic nature of human beings as both physical and social beings. In congruence, the European Commission (2007) defines poverty as individuals and groups of persons whose limited resources have excluded them from enjoying life at the minimum acceptable level considered by the Member State they belong. However, 
Nyasulu (2010) argues this definition concentrates on the individual entity whose level of resources would exclude them from the minimum acceptable way of life deemed acceptable by a member state. He contests that the definition assumes that it is acceptable to be in certain conditions, however deplorable as long as the member state has not declared them as such, and thus abrogates the responsibility of focusing on a less contentious issue of 'person' or 'group of persons' in a member state. Nyasulu (2010) argues that poverty should be viewed as a condition that undermines individuals' dignity, and further indicates that poverty is not what a member state says or thinks, or what a particular culture accepts. But rather, "poverty is poverty, regardless of one's geographic location and has everything to do with the dignity of the human spirit in particular conditions and not what is considered politically correct or culturally acceptable" (Nyasula, 2010, p.149).

Other attempts to understand and describe the poverty concept have been related to the environment and governance. In relation to environmental definition of poverty, the UNDP and UNEP (2009) explain that poor people especially in developing countries depend excessively on natural resources and the environment for their livelihood and are most vulnerable to natural and environmental disasters (e.g. floods and droughts). As a result, many regions of the world are trapped in a vicious downward spiral as poor people are compelled to overuse environmental resources to survive from day to day leading to environmental impoverishment which further impoverishes them (WCED, 1987). This situation aggravates the poverty conditions and makes the survival of the poor more difficult and uncertain (WCED, 1987). Governance has also crept into the global poverty discourse (Adejumobi, 2006). Given that governance provides the institutional, legal and political frameworks for structuring poverty reduction strategies and improving the capacity of the poor in terms of enhancing their material conditions, it has become central in poverty discussions as without good governance bad policies ensue which consequently results in lack of participation and power among the poor (Adejumobi, 2006). Thus, getting governance right is key in poverty reduction as issues relating to voice and power for the poor and the vulnerable in society center on the appropriateness of the governance system (Adejumobi, 2006).

The concept of poverty has also been defined in 'absolute' and 'relative' terms (Noble et al., 2004; Sen, 2000; UN, 1995; World Bank, 2000). The concept of 'absolute' poverty refers to poverty that exists independently of any reference group, and does not depend on the general living standards of the society in which it is conceived (Nobel et al., 2004). Noble et al. (2004) view 'absolute' poverty as a situation or condition pertaining to a specific locality or group, not a globally accepted pattern of life, and thus poverty solutions must be context specific. According to the UN (1995) 'absolute' poverty is defined as a condition characterized by severe deprivation of basic human needs, including food, safe drinking water, sanitation facilities, health, shelter, education and information. Economically, this approach perceives poverty as not having an adequate income level to enable a person or household to satisfy basic needs such as food, clothing and shelter (Nyasulu, 2010). Absolute poverty is the situation where poverty is usually measured by the value, in real terms, of a given level of goods ensuring some form of minimum subsistence, that is, the value of basic food or the minimum income required to have decent lives (Bellu, 2005). Although Alcock (1993) claims that absolute poverty is objective and represents a scientific notion, it has been argued that definitions of absolute poverty contain some elements of relativity (Noble et al., 2004). The 'relative' concept of poverty connotes a standard of living in relation to the position of other people in the income/expenditure distribution, and defines poverty basically as a phenomenon of inequality (Bellu, 2005). The issue on absolute and relative concepts of poverty definition has been widely debated in the poverty literature (Noble et al., 2004; UN, 1995), however, "poverty is neither a strictly absolute nor a strictly relative concept" (Seidl, 1988, p.79).

The multidimensionality of poverty is recognized as a global phenomenon as stakeholders are constantly confronted with the severity of poverty (Nyasulu, 2010). As a consequence of its universal recognition, the UN (1995) describes it "as mass poverty in many developing countries, pockets of poverty amid wealth in developed countries, loss of livelihoods as a result of economic recession, sudden poverty as a result of disaster or conflict, the poverty of low-wage workers, and the utter destitution of people who fall outside family support systems, social institutions and safety nets" (p.41).

\section{Poverty Reduction Approaches in the Developing Countries}

Underscoring the differences in the understanding of the poverty concept, this section reviews poverty reduction approaches in the developing countries over the past 50 years. Historically, the term 'poverty reduction' in developing countries has been used purposely to refer to direct interventions in the provision of facilities that are lacking, and finding solutions to deficiencies in infrastructure with investments from international lending agencies (Singleton, 2003). Poverty reduction approaches have evolved over the past 50 years in response to a deepening understanding of the complexity of development (Domfeh \& Bawole, 2009; World Bank, 2000). 
In the 1950s and 1960s large investments in physical capital infrastructure, according to Domfeh and Bawole (2009) were regarded as a primary way of addressing poverty. Despite this approach, poverty was pervasive due to lack of planning for the ongoing operation and maintenance of the facilities, limited attention to the development of a sense of ownership by the local community, political interference and intervention, and corruption leading to ineffectiveness of investment (Singleton, 2003).

To achieve poverty reduction, there was a gradual shift of focus in the 1970s from physical capital infrastructure development to health and education (Domfeh \& Bawole, 2009). The World Development Report 1980 (World Bank, 1980) articulated this understanding and argued "that improvements in health and education were important not only in their own right, but also to promote growth in the incomes of poor people" (World Bank, 2000, p. 6). However, Fukuda-Parr (2006) believes that strategies to alleviate poverty should not be limited to only economic growth and redistribution, but should incorporate interventions in areas such as expansion of education, combating discrimination and achieving social justice.

During the 1980s, another shift of emphasis of poverty reduction occurred following the debt crisis and global recession and the contrasting experiences of East Asia and Latin America, South Asia, and Sub-Saharan Africa (World Bank, 2000). Greater emphasis was placed on improving economic management while allowing greater interplay for market forces (World Bank, 2000). The World Development Report, 1990 states that the period of 1980s saw a two-part strategy of promoting labour-intensive growth through economic openness and investment in infrastructure, and providing basic services to poor people in health and education (World Bank, 2000). However, overconcentration on economic growth and development to the neglect of socio-political factors impeded this poverty reduction strategy (World Bank, 2000).

As presented in Table 2, the 1990s was characterized by the World Bank's 'Poverty Reduction Strategy Papers' (PRSPs) as a model for reducing poverty especially in the developing world. The PRSPs focused on improving governance structures and social institutional frameworks as well as ensuring wider community participation (World Bank, 2003). In spite of the progress made with the introduction of the PRSPs, the World Bank finds that increasing political instability coupled with weak institutions in many developing countries has prevented the realization of the PRSPs objective of reducing poverty.

Since 2000 , poverty reduction has increasingly become a rights-based issue, leading to its endorsement by the international community as a universal norm through the MDGs (Adejumobi, 2006). The MDGs approach advocates for the empowerment and involvement of local community in development decision-making process, involvement of national and regional governments and the pursuit of growth oriented projects (Singleton, 2003). The period was characterized by improvement in governance and institutions as issues of vulnerability at the local and national levels moved to the center stage of global discussion (World Bank, 2000).

However, Todaro and Smith (2006) have argued that despite the significant attempts to reduce poverty over the past half a century, the poverty situation is persistent in the developing countries. The persistence of poverty has been largely due to lack of consideration of local poverty issues, and inappropriate implementation and management strategies which led Singleton (2003) to define poverty reduction as an approach that requires interventions involving considerable social and cultural change. According to Singleton (2003), the multifaceted nature of poverty requires more than technical and engineering solutions which can be provided from the international level. Thus, Asante and Ayee (2004) define poverty reduction as designing and implementing appropriate strategies to ensure effective use of scarce resources by allocating resources to activities that have the potential to yield maximum impact on the poor and contribute to reducing deprivation and vulnerability in poor communities.

Poverty reduction has been a sustainable development approach in many countries especially the developing countries over the past decades (Todaro \& Smith, 2006). For example, over the past decade, PRSPs have been adopted as blueprints for poverty reduction in many countries (Domfeh \& Bawole, 2009). In 1999, a new framework for PRSPs was endorsed by the IMF and the World Bank (Bojo \& Reddy, 2002). The PRSPs hinge on the principles of sustainable development and the World Bank $(2001,2003)$ outlines the following as the focus of the PRSPs:

- country-driven with broad participation of civil society;

- based on an understanding of the links between public actions and poverty outcomes;

- comprehensive in scope, recognizing the multidimensional nature of the causes of poverty and measures to attack it;

- oriented to achieve outcome-related goals for poverty reduction; 
- partnership-oriented, providing a basis for the active and coordinated participation of development partners in supporting country strategies; and

- based on a medium and long-term perspective for poverty reduction, realizing that poverty reduction cannot be achieved immediately.

The recognition of the importance of country ownership and participation in poverty reduction interventions led Stiglitz (2002) to remark that effective change and successful transformation can only result when there is local ownership and participation, and less outside imposition. Commenting on the need for ownership and participation, the 'World Development Report 2000/2001' proposed a poverty reduction strategy which is human-centered and geared towards the realization of the MDGs. The poverty reduction strategy focuses on three areas: promoting opportunity, facilitating empowerment, and enhancing security (World Bank, 2000):

(1) Promoting opportunity. Poor people in the developing countries consistently emphasize the centrality of material opportunities such as jobs, credit, roads, electricity, markets for their produce, and the schools, water, sanitation, and health services that underpin the health and skills essential for work. In the developed countries with high inequality, greater equity is particularly important for rapid progress in alleviating poverty. This strategy emphasizes the overall economic growth and requires action by the state to support the build-up of human, land, and infrastructure assets that poor people own or to which they have access;

(2) Facilitating empowerment. The choice and implementation of public actions that are responsive to the needs of poor people depend on the interaction of political, social, and other institutional processes. Achieving access, responsibility, and accountability is intrinsically political and requires active collaboration among poor people, the middle class, and other groups in society, and can be facilitated by changes in governance that make public administration, legal institutions, and efficient public service delivery. This approach aims at removing the social and institutional barriers that result from distinctions of gender, ethnicity, and social status; and

(3) Enhancing security. Reducing vulnerability to economic shocks, natural disasters, ill health, disability, and personal violence is an intrinsic part of enhancing well-being and encourages investment in human capital. This approach requires effective national action to manage the risk of economy-wide shocks and effective mechanisms to reduce the risks faced by poor people, including health and weather-related risks.

Table 2. Poverty reduction approaches, focus and challenges

\begin{tabular}{|c|c|c|c|}
\hline Period & Approach & Focus & Weaknesses/Challenges \\
\hline $1950 \mathrm{~s}-1960 \mathrm{~s}$ & Capital investment & $\begin{array}{l}\text { Development of physical } \\
\text { infrastructure }\end{array}$ & $\begin{array}{l}\text { 1. Lack of planning for } \\
\text { ongoing operation and } \\
\text { maintenance of facility. } \\
\text { 2. Lack of sense of community } \\
\text { ownership }\end{array}$ \\
\hline 1970s & Social investment & $\begin{array}{l}\text { Improvement in health and } \\
\text { education }\end{array}$ & Global recession and debt crisis \\
\hline $1980 \mathrm{~s}$ & $\begin{array}{l}\text { 1.Promoting labour intensive } \\
\text { growth through economic } \\
\text { openness and investment } \\
\text { 2. Providing basic services }\end{array}$ & $\begin{array}{l}\text { Improving economic } \\
\text { management }\end{array}$ & $\begin{array}{l}\text { Lack of social and political } \\
\text { interventions }\end{array}$ \\
\hline $1990 \mathrm{~s}$ & $\begin{array}{l}\text { Poverty Reduction Strategy } \\
\text { Papers (PRSP) }\end{array}$ & $\begin{array}{l}\text { Sustainability, community } \\
\text { participation, improvement in } \\
\text { governance and social } \\
\text { institutions }\end{array}$ & $\begin{array}{l}\text { Weak institutions, } \\
\text { lack of enforcement }\end{array}$ \\
\hline $2000 \mathrm{~s}$ & $\begin{array}{l}\text { Millennium Development } \\
\text { Goals (MDGs) }\end{array}$ & $\begin{array}{l}\text { Health, education, } \\
\text { environment, security, } \\
\text { empowerment, partnership }\end{array}$ & \\
\hline
\end{tabular}

Table 2 shows that the universal poverty reduction approaches adopted over the past six decades have been faced with many challenges particularly with planning and enforcement. Cobbinah, Black and Thwaites (2011) explain that weak institutions and political instability in many developing countries particularly in Africa are key challenges to development interventions, and ought to be addressed to ensure that the well-being of the poor and vulnerable is improved. However, these problems continue to persist in many developing countries of Africa (e.g. 
Sudan, Somalia) and often lack international policy interventions. For example the current MDGs approach has had many successes in developing countries over the past decade (UN, 2013) but Sachs (2012) argues that many of the MDGs targets will not be met by the end of the plan period (2015) because of operational challenges that implicate many stakeholders. This emphasizes the unsustainabilty of universal approaches to poverty reduction without adequate consideration to the needs and the level of development of the various countries, especially those in the developing world.

\section{Discussions}

The above discussions on poverty have revealed the multidimensional nature of the phenomenon and its influence across the globe particularly on developing countries. Over the past six decades the definitions of poverty have been broadened beyond economic indicators (e.g. income) to include social and cultural indicators (e.g. education and health) which better define and reflect the well-being of people, despite the lack of an internationally agreed definition. As Nyasulu (2010) claims, poverty has now become a global social problem with its influence being experienced across different regions of the world particularly developing countries, although the form and nature vary (Domfeh \& Bawole, 2009). Despite the differences in the nature of poverty across different regions, universal poverty reduction approaches have been adopted over the past half a century. However, the peculiarity of the poverty phenomenon in every country has made these poverty reduction efforts less effective as Todaro and Smith (2006) maintain that poverty conditions especially in the developing countries are pervasive.

Within the context of many definitions of poverty and ineffective universal poverty reduction approaches, Noble et al. (2004) suggest that although poverty is a global phenomenon, efforts to address it should be context specific. While it is imperative to recognize the global nature of poverty, it is more important to use locally feasible strategies to tackle the phenomenon in different countries as this can yield effective results rather than global approaches. As Stiglitz (2002) asserts, ensuring local ownership and participation in poverty reduction efforts and minimizing outside imposition are critical in alleviating poverty in developing countries. Given that developing countries especially in Africa are characterized by civil wars, devastated agriculture, collapsed infrastructure, and political repression as well as HIV/AIDS (Ayittey, 2005), local poverty reduction strategies that focus on addressing these challenges are key in achieving positive poverty reduction outcomes.

As Cobbinah et al. (2011) assert, the understanding of poverty at the local level as well as strategies to improve the poverty situation in developing countries is important in achieving sustainable development. With the definitions of poverty revolving around deprivation in developing countries, poverty reduction thinking especially in Africa should not be centered on satisfying international conventions and policies but improving the well-being of the poor through quality education, employment opportunities, good health, participation, environmental awareness education and the implementation of locally oriented development programs (Cobbinah et al., 2011). Cobbinah et al. (2011) further emphasized that ensuring sustainable poverty reduction and development in developing countries requires strong institutions to implement locally targeted poverty reduction policies which are necessary to improve the well-being of the poor.

\section{Conclusion}

Central to this paper is the understanding of the dynamics of poverty in the developing countries. The paper has established there are different perspectives on the concept of poverty amongst researchers, practitioners, governments and non-government organizations. However, the understanding of poverty in developing countries have been expanded over the years to include key issues including lack of access to and quality of basic social services, lack of participation and powerlessness, environmental degradation, poor health, and poor quality of education.

Despite the different conceptualizations of the concept of poverty, poverty reduction approaches over the past 50 years, have been general and collective for all regions and all people (e.g. MDGs). It is therefore not surprising that Todaro and Smith (2006) assert that poverty conditions are worsening in developing countries despite the numerous poverty reduction approaches. The above discussions show that the diversity in the understanding of poverty with respect to different regions in developing countries require strategies that are locally feasible in reducing poverty rather than universally agreed strategies.

It is important to recognize poverty as a global phenomenon as it creates consciousness among stakeholders in relation to how it should be addressed. However, local level indicators should be adopted in addressing poverty in developing countries. Given that poverty in the developing countries largely revolves around deprivation and lack of access to basic services, governments and non-governmental organizations should direct efforts towards meeting the basic needs of the people. Additionally, governments of the developing countries should be 
committed to ensuring stable political and economic environments which are necessary ingredients for poverty reduction and sustainable development. According to Cobbinah et al. (2011), ensuring stable political and economic environments are critical to ensure that local institutions function to improve the well-being of the poor while contributing to sustainable development.

\section{Acknowledgement}

This research forms part of a PhD thesis that is funded by Charles Sturt University, Australia. The authors are particularly grateful to the Faculty of Science, Charles Sturt University for sponsoring this study.

\section{References}

Adejumobi, S. (2006). Governance and poverty reduction in Africa: A critique of the poverty reduction strategy papers (PRSPS). A paper presented to the "Inter-Regional Conference on Social Policy and Welfare Regimes in Comparative Perspectives". Texas University, USA, pp.1-31.

Alcock, P. (1993). Understanding poverty. Basingstoke: McMillan.

Asante, F., \& Ayee, R. A. (2004). Decentralization and poverty reduction. In Ernest Aryetey and Ravi Kanbur (editors) (2008). The economy of Ghana: Analytical perspectives on stability, growth and poverty. James Currey. Retrieved from www.saga.cornell.edu

Ashiomanedu, J. (2008). Poverty and sustainable development in the Niger delta region of Nigeria. Journal of Sustainable Development in Africa, 10(3), 155-171.

Atinmo, T., Mirmiran, P., Oyewole, O. E., Belahsen, R., \& Serra-Majem, L. (2009). Breaking the poverty/malnutrition cycle in Africa and the Middle East. International Life Sciences Institute, Nutrition Reviews, 67(Suppl. 1), S40-S46. http://dx.doi.org/10.1111/j.1753-4887.2009.00158.x

Ayittey, G. (2005). Africa unchained: The blueprint for Africa's future. New York: Palgrave Macmillan.

Bastiaensen, J., De Herdt, T., \& D'Exelle, B. (2005). Poverty reduction as a local institutional process. World Development, 33(6), 979-993. http://dx.doi.org/10.1016/j.worlddev.2004.09.019

Bellu, L. G. (2005). Impacts of policies on poverty: The definition of poverty. Food and Agriculture Organization of the United Nations, FAO. Retrieved from www.fao.org/tc/easypol

Bojo, J., \& Reddy, C. R. (2002). Poverty reduction strategies and environment: A Review of 40 interim and full Poverty Reduction Strategy Papers. Washington: The World Bank Environment Department, pp.1-46.

Chambers, R. (1983). Rural development: Putting the last first. Prentice Hall.

Cobbinah, P. B., Black, R., \& Thwaites, R. (2011). Reflections on the six decades of the concept of development: evaluation and future research. Journal of Sustainable Development in Africa, 13(7), 134-149.

Deguara, A. (2008). The faces of the poor: A sociological review of poverty in contemporary. Europe and Malta. Retrieved from www.um.edu.mt/edrc/books/CD_CSP4/pdf/adeguara.pdf

Domfeh, K. A., \& Bawole, J. N. (2009). Localizing and sustaining poverty reduction: experiences from Ghana. Int. Journal of Management of Environmental Quality, 20(5), 490-505. Emerald Group Publishing Limited. http://dx.doi.org/10.1108/14777830910981186

European Commission. (2007). Social inclusion and income distribution in the European Union. Monitoring Report. Social Inclusion and Income Distribution Network.

Fukuda-Parr, S. (2006). The human poverty index: A multidimensional measure. International Poverty Centre, UNDP: Poverty in Focus, December. pp. 7-9.

Ghai, D. P. (1977). The basic needs approach to development: Some issues regarding concepts and methodology. Geneva: International Labour Office.

Haughton, J. H., \& Khandker, S. R. (2009). Handbook on poverty and inequality. Washington, D. C: World Bank

Hobsbawm, E. J. (1972). The social function of the past: some questions. Past and Present, 55(1), 3-17. http://dx.doi.org/10.1093/past/55.1.3

Jamieson, W., \& Nadkarni, S. (2009). A reality check of tourism's potential as a development tool. Asia Pacific Journal of Tourism Research, 14(2), 111-123. http://dx.doi.org/10.1080/10941660902847161

Knowles, J. C. (2000). A look at poverty in the developing countries of Asia. East-West Center, Asia-Pacific Population and Policy, No. 52, January, pp.1-4. 
Lehning, A. J., Vu, C. M., \& Pintak, I. (2006). Theories of poverty: Findings from textbooks on human behaviour and the social environment. In Understanding poverty from multiple social science perspectives Bay Area Social Services Consortium. School of Social Welfare, University of California, Berkeley.

Longres, J. (2000). Human behaviour in the social environment. Belmont, CA: Wadsworth/Thompson Learning.

Morazes, J., \& Pintak, I. (2006). Theories of global poverty: Comparing developed world and developing world frameworks. In Understanding poverty from multiple social science perspectives, pp. 145-169. Bay Area Social Services Consortium. School of Social Welfare, University of California, Berkeley.

Noble, M., Ratcliffe, A., \& Wright, G. (2004). Conceptualising, defining and measuring poverty in South Africa: An argument for a consensual approach. Center for South African Social Policy. Oxford University, U.K. Retrieved from www.casasp.ox.ac.uk

Nussbaum, M., \& Sen, A. (1993). The quality of life. Oxford: Clarendon Press. http://dx.doi.org/10.1093/0198287976.001.0001

Nyasulu, G. (2010). Revisiting the definition of poverty. Journal of Sustainable Development in Africa, 12(7), 147-158.

Pearce, D., \& Barbier, E. (2000). Blueprint for a sustainable economy. London: Earthscan Publications Ltd.

Pillari, V., \& Newsome, M. (1998). Human behaviour in the social environment: Families groups, organizations, and communities. Pacific Grove, CA: Brooks/Cole

Random House Incorporated. (2009). Random House Webster's unabridged dictionary (2nd Ed.). Manhattan, USA: Random House Publishing. Retrieved from http://dictionary.reference.com/browse/poverty

Rao, M. G. (2003). Poverty alleviation under fiscal decentralization. National Institute of Public Finance and Policy, New Delhi, India, pp. 1-29. Retrieved from www.nipfp.org.in

Ravallion, M. (2003). Targeted transfers in poor countries: Revisiting the trade-offs and policy options. Social Protection Discussion Paper Series, World Bank. Retrieved from www.worldbank.org/sp

Rupasingha, A., \& Goetz, S. J. (2003). The causes of enduring poverty an expanded spatial analysis of the structural determinants of poverty in the US. The Northeast Regional Centre for Rural Development, Rural Development Paper No. 22. Retrieved from http://www.cas.nercrd.psu.edu

Sachs, J. D. (2012). From millennium development goals to sustainable development goals. Viewpoint, 379, 2206-2211.

Schriver, J. (2004). Human behaviour and the social environment: Shifting paradigms in essential knowledge for social work. San Francisco: Pearson Education Inc.

Seers, D. (1969). The meaning of development. International Development Review, 11(4), 2-6.

Seidl, C. (1988). Poverty measurement: A survey. In D. Bos, M. Rose, \& C. Seidl (eds), Welfare and efficiency in public economics, Springer, New York, USA. pp. 71-147. http://dx.doi.org/10.1007/978-3-642-73370-3_4

Sen, A. (1992). Inequality re-examined. Oxford: Clarendon Press.

Sen, A. (1996). On the status of equality. Political Theory, 24(3), 394-400. http://dx.doi.org/10.1177/0090591796024003004

Sen, A. (2000). Social exclusion: Concept, application \& scrutiny. Social Development Papers 1, Manila: Asian Development Bank.

Simon, M. (1999). The meaning and measurement of poverty. Overseas Development Institute Poverty Briefing, Vol. 3, February, pp. 1-4. London: Portland House.

Singleton, D. (2003). Poverty alleviation: the role of the engineer. The ARUP Journal, 3-9.

Stiglitz, J. (2002). Globalization and its discontents. New York: W.W. Norton.

Sumner, A. (2007). Meaning versus measurement: Why do 'economic' indicators of poverty still predominate? Development in Practice, 17(1), 4-13. http://dx.doi.org/10.1080/09614520601092485

Thompson, A. R. (1981). Education and development in Africa. New York: St. Martins' Press.

Todaro, P. M., \& Smith, S. C. (2006). Economic Development, (9th ed.). Washington D.C.: Pearson Education, Harlow.

Townsend, P. (1979). Poverty in the United Kingdom. U.K: Harmondsworth. 
United Nations. (1995). The Copenhagen Declaration and Programme of Action: World Summit for Social Development 6-12 March 1995, United Nations Department of Publications: New York.

United Nations. (2000). United Nations millennium declaration. Resolution 55/2, United Nations A/RES/55/2, 18 September 2000, UN.

United Nations. (2002). Report of the world summit on sustainable development. Johannesburg South Africa E.03.II.A.1. United Nations, New York.

United Nations. (2010). Millennium Development Goals. Retrieved from www.mdgs.un.org

United Nations. (2013). The Millennium Development Goals Report, 2013. United Nations, New York.

United Nations Development Program [UNDP]. (1990). Human development report. New York: Oxford University Press.

United Nations Development Program [UNDP]. (2005). International cooperation at a crossroads: aid, trade and security in an unequal world, Human Development Report. Retrieved from www.undp.org.

United Nations Development Program [UNDP] \& United Nations Environment Program [UNEP] (2009). Mainstreaming poverty-environment linkages into development planning: A handbook for practitioners. $\begin{array}{lllll}\text { UNDP-UNEP Poverty-Environment } & \text { Initiative } & \text { Retrieved }\end{array}$ http://www.unpei.org/PDF/PEI-full-handbook.pdf

Vollmer, F. (2010). Reviewing 'poverty' as an object of study: Seeking a conceptual match of well-being with the inter-subjective understanding of ill-being. In-Spire Journal of Law, Politics and Societies, 5(2), 67-85.

Watkins, K. (2005). Human development report, 2005. Retrieved from http://hdr.undp.org/reports/global/2005

Whelan, C. T. (2007). Measuring consistent poverty in Ireland. The Economic \& Social Review, 38(2), 211-234.

World Bank. (1980). World development report 1980. Washington: World Bank. http://dx.doi.org/10.1596/978-0-1950-2834-8

World Bank. (1999). Voices of the poor. Synthesis of participatory poverty assessments. Washington D.C. World Bank Publishing.

World Bank. (2000). World development report 2000/2001.New York: Oxford University Press.

World Bank. (2001). Poverty reduction strategy sourcebook. Washington: World Bank.

World Bank. (2003). World Bank participatory poverty assessment for Niger. Washington, DC.

World Commission on Environment \& Development [WCED]. (1987). Our common future. Report of the Brundtland Commission. U.K: Oxford University Press.

\section{Copyrights}

Copyright for this article is retained by the author(s), with first publication rights granted to the journal.

This is an open-access article distributed under the terms and conditions of the Creative Commons Attribution license (http://creativecommons.org/licenses/by/3.0/). 